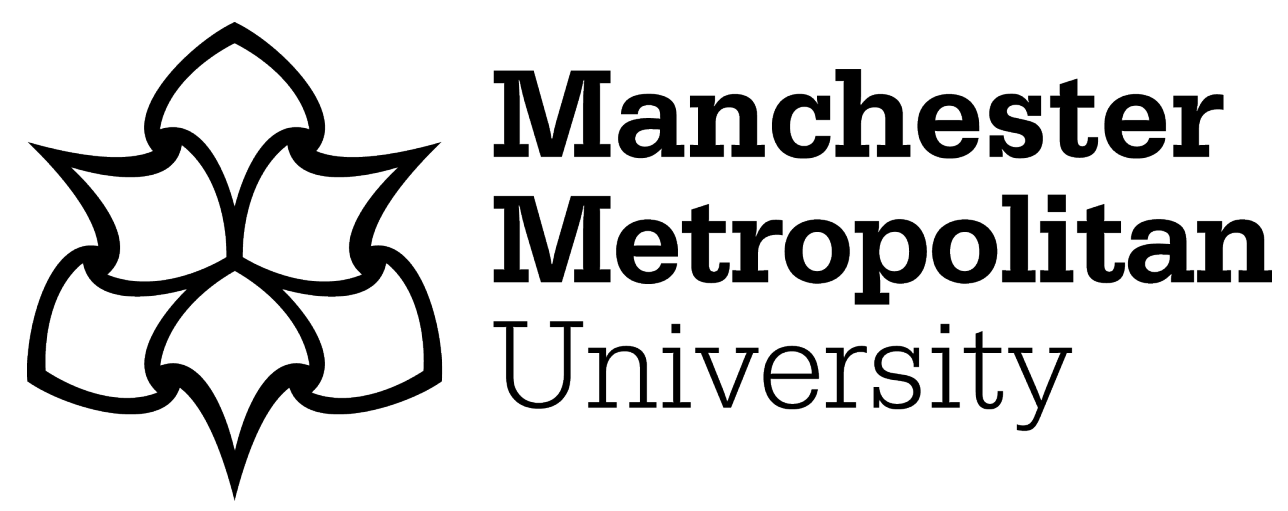

Borzenkova, Ganna, Niedderer, Kristina ORCID logoORCID: https://orcid.org/0000-0002-8188-6338 and Rozsahegyi, Tunde (2018) Designing Play Equipment for Children with Cerebral Palsy: the context and design guidelines. In: Design Research Society Conference 2018, 25 June 2018 - 28 June 2018, University of Limerick.

Downloaded from: https://e-space.mmu.ac.uk/624375/

Version: Published Version

Publisher: Design Research Society

DOI: https://doi.org/10.21606/drs.2018.491

Usage rights: Creative Commons: Attribution-Noncommercial-Share Alike 4.0

Please cite the published version 


\title{
Designing play equipment for children with cerebral palsy: the context and design guidelines
}

\author{
BORZENKOVA Ganna ; NIEDDERER Kristina and ROZSAHEGYI Tunde \\ University of Wolverhampton, UK \\ *g.a.borzenkova@wlv.ac.uk \\ doi: 10.21606/dma.2017.491
}

\begin{abstract}
This paper presents an investigation into designing play equipment for encouraging peer-to-peer social interactions of children with cerebral palsy as a part of developing their social competence. The focus is on developing a new model of, and guidelines for designing play equipment for engaging children in peer interactions during play sessions. Research projects on the development of children with cerebral palsy have to date mainly concentrated on physical and cognitive areas or on social development through special educational programmes and training. This paper, in contrast, investigates developing social competence through empowering children to participate in open-ended peer play through a new model of play equipment.
\end{abstract}

Child-centred design; peer social competence; cerebral palsy; play equipment

\section{Introduction}

Despite the modern achievements of medicine, the birth of a child may entail unforeseen consequences connected with numerous disorders. Infantile cerebral palsy is one of them. The issue of early intervention, development and sustentation of health conditions for these children requires a comprehensive and complex approach. According to the statistics of the National Health Service (NHS 2016), it is estimated that 1 in 400 people in the UK is affected by cerebral palsy.

Approximately 1800 children are diagnosed with cerebral palsy every year. There are an estimated 30000 children with cerebral palsy in the UK (NHS 2016).

The most direct definition of cerebral palsy is that it is one of the most common forms of physical disability amongst young children (Parkes et al, 2001). Rozsahegyi (2014, p.47-53) examines a range of definitions of cerebral palsy and observes that the available explanations are often medical in nature. As a result, support for these children is often medical in nature and focuses on problems of motor coordination, balance and mobility, gross and fine movement (Cogher et al. 1992; Farrell 2008; Hinchcliffe 2007), while the picture of how cerebral palsy affects the child's development is much broader. 
In Vygotsky' socio-cultural view, cerebral palsy is seen as a developmental disorder with two kinds of implications: primary - the neurological, biological impairment, secondary - the social and cognitive implications which hinders the child to participate in everyday activities. The importance of the Vygotskian view is that the secondary implications make the child 'disabled'. He stresses the importance of social interactions and states that socialisation plays a significant role in children's development. Palmonari \& Doise (1984) also draw attention to the importance of social interaction in development. They argue that social interaction and collaboration are critical components of development. In spite of this recognition of the importance of social interactions, it is still insufficiently studied.

As a group, children with cerebral palsy perform less well socially than do peers with typical development (McConnell and Odom 1999, pp.67-74). According to Guralnick et al. (1996, pp.359377), children with cerebral palsy, when compared to typically developing children of similar ages, interact with peers less often and are less well accepted. Children who do not have a basic level of social competence by the age of six may have difficulties with relationships when they will be adults (Blandon et al. 2010; Ladd 2000; Parker \& Asher 1987). The fundamental outcomes that need to be achieved for many disabled children and young people according to Department of Education (DfE, 2014) are communication. From the above, the idea of addressing social competence for these children was derived, as this is an important prerequisite for their holistic development.

The primary context for the development of social competence is play interaction with peers (Goldstein 2012, pp.5-8; Whitebread 2012, pp.5-6). During play, children are able to test out social roles and learn acceptable social rules. They are encouraged to share, take turns, cooperate, consider others' perspectives, and acquire self-control (Bracken, 2000; Gagnon \& Nagle, 2004). The opportunity to play and explore provides children with the ability to learn about likeness and differences, acceptance and understanding, and socialization in a way that cannot be taught through any other means.

All children learn through play, but play does not come naturally to all children. Sometimes the right tool can spark enough interest to start something new. The term for tools used in children's play is play equipment. As part of the physical environment, it has the ability to contribute or retard developmental process. Designing play equipment that are appropriate for children with cerebral palsy can be challenging. This project is primarily focused on clarifying the issues that must be taken into consideration when designing play equipment for developing social competence of children. Play equipment in this study is regarded not only as a part of physical environment or tool for children to play with. Here play equipment is treated as a tool for engaging children into child object - child interactions.

Encouraging social competence development of children with cerebral palsy is a challenging aim and addresses deep issues about the nature of social interactions and social skills. Studying play equipment as mediators in this domain adds an additional level of complexity. However, when approaching this challenge from the bottom up, taking it step by step, this project will provide evidence as to the possible role of play equipment in development of the social competence of children with cerebral palsy, and can contribute into understanding how can one approaches to create play equipment for children with cerebral palsy, by providing design guidelines for such equipment.

This paper outlines the context and the key concepts for designing play equipment for early years children with cerebral palsy that encourage them to engage in open-ended play with other children and foster their social development. To understand the peculiarities of children and to define criteria and requirements for designing such play equipment, the discussion begins with the conception of cerebral palsy and an outline of the current status of medical and social views on cerebral palsy. This is followed by the discussion of the importance of the development of social competencies. Based on this, the concept of play, and play equipment as a means to play are presented. The contextual 
review finishes by outlining the theoretical concept and design criteria for creating a new model of play equipment.

\section{Medical and social views on cerebral palsy}

As a basis for the discussion, it is necessary to consider what cerebral palsy is since cerebral palsy has been conceptualised and defined in a number of ways.

The medical perspective of cerebral palsy focuses on problems of motor coordination, balance and mobility, gross and fine movement, combined with cognitive and perceptual difficulties (Cogher et al. 1992; Fox 2003; Farrell 2008; Hinchcliffe 2007). Such a view advocates professional physiotherapeutic means of rehabilitation and development to compensate the impact of cerebral palsy (Rozsahegyi 2014, p.7-53), which is easiest to observe and measure in all patients. But even if the motor abilities of the patient increase, the psychological distress and social engagement may not necessarily decrease (Parkes 2008, pp.405-413; Landsman 2006, pp.2670-2680; Landsman 2005, pp.121-139).

While physio-therapeutic support of children remains dominant in the United Kingdom, Rozsahegyi $(2014, p .21)$ has argued that such an approach encourages only the child's passive participation and emphasizes the dysfunction, rather than its abilities. Hári and Ákos (1988), Hári (1997, pp.17-33) and Sutton (2010, pp.xi-xiii), for instance, stress the significance of the emotional, social and cognitive difficulties which the child faces as the result of physical disability and ways how these difficulties may be overcome. Vygotsky (1978, p.79-91), Kozulin (1990, p.254), and Meadows (1993, pp.104126) believe that the development of the child arises from his/her attempts to deal with everyday problems and from interactions with the child's environment.

According to Vygotsky (1929, vol.2) children with disabilities are not limited by defects or less developed in comparison to their peers without disability, but they develop differently. The personality of a child with disability is something special and not the sum of any 'defects' or 'limitations'. Moreover, any defect creates incentives for compensation (Stern 1923, p.145 cited in Vygotsky 1929, vol.2). This does not only mean physical compensation, but also psychological. The positive difference of disabled children is created not because of lack of certain functions that a child with typical development has, but because this lack triggers a unique personal reaction to the disability and a unique compensatory mechanism.

According to Vygotsky $(1978$, p.57) 'every function in the child's development appears twice: first on the social level and later on the individual level; first, between people and then inside the child'. For example, initially a child's gestures can be just motions without particular meaning. However, when people respond or react to the gestures, they become meaningful. Then, after a child comprehends, they can be used for social communication. A number of skills which can be developed with social guidelines and collaboration are often wider than skills which can be developed alone (Fani and Ghaemi 2011, p.1550). The social environment influences the developmental uniqueness (Scherbina 1916, p.10 cited in Vygotsky 1929, vol.2; Burklen 1924 cited in Vygotsky 1929, vol.2). Compensatory processes are also socially determined and are directed on overcoming difficulties caused by the defect and not directly on overcoming the defect which is often impossible. Rogoff (1990, pp.171$188 ; 1998$, p.686), based on the work of Vygotsky, emphasised the social nature of children's development. Further evidence that supports the idea that it is important for children with disabilities to be integrated in society and not to be treated differently and to be isolated can be found in a number of personal stories and experiences from people with cerebral palsy provided by the "My Child" informational website (2016).

These stories indicate that social aspects in the development of disabled children play a vital role, but are still addressed insufficiently. Despite a diversity of views and definitions, the effects of cerebral palsy are clearly visible in children's lives, shaping their experiences and participation in 
social life (Rozsahegyi 2014, p.52). In the following, this paper therefore discusses the social development of children in more detail.

\section{Social competence for children with cerebral palsy}

"Social competence refers to a child's ability to get along with and relate to others" (AEDC 2011, p.2). Being socially competent involves many elements, including the ability to regulate emotions, developing knowledge and experience of social interactions and understanding social situations and customs (Katz \& McClellan, 1997). For young children, social skills include learning to be a friend, to negotiate personal needs and deal with difficulties, to be assertive without being aggressive and to relate effectively with adults and peers (Linke, 2011).

Social competence is interrelated with other aspects of development and should be seen as being important in young children's development as physical, emotional and cognitive development. (Blandon et al. 2010). The holistic approach understands children's development to consist of these inter-dependent dimensions. Children's holistic learning and development 'involves all areas of development and embraces a view of the whole child developing in the context of family, home and community' (NCCA 2007, p.12). Based on the above, the progress in one area affects progress in others and if one area of the development is strengthened we can anticipate development in other areas. The possible difference between development of children with cerebral palsy and children with typical development can be represented as follows (figure 1):

\section{DEVELOPMENT OF THE CHILD WITH CEREBRAL PALSY}

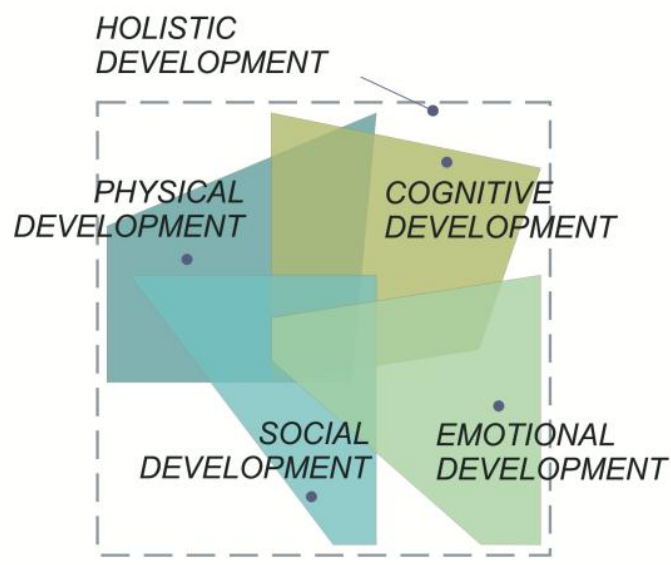

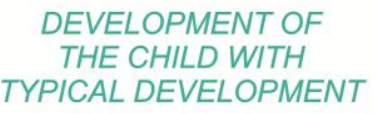

HOLISTIC

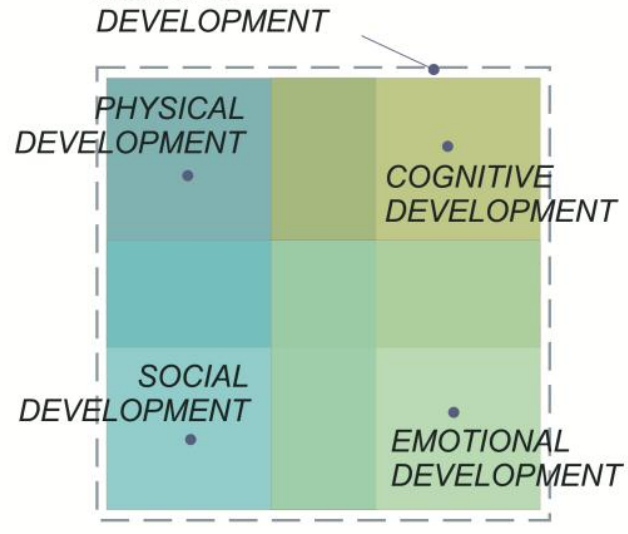

Figure 1 The possible difference between development of the child with cerebral palsy and the child with typical development

During the early years, social competence involves the ability to separate from parents and engage with peers in shared play activities (2017, informational website "Children's health"). Social competence includes 'knowing what is expected for social interactions, such as making eye contact, taking turns, listening to others, not being aggressive; "reading" other people's facial expressions and gestures; recognizing emotions in others and oneself; and being able to communicate effectively with others, including family members, peers, and adults' (2016, informational website "Happy Tots").

As early years children are just learning to coordinate their social behaviour, their interactions are often short and marked by frequent quarrel, and friendships are less stable than at later developmental stages. During the early years, children are primarily focused on group acceptance and having companions with whom they can play (AEDC 2011, p.2). Thereby, the development of 
social relationships with peers is one of a major achievement of the early years for children (Guralnick 2001, pp.3-35) and is the focus of this research.

Disabled children have broadly the same aspirations in social acceptance as non-disabled children and the outcomes they would like to achieve are therefore similar. However, for many disabled children and young people, there are fundamental outcomes that need to be achieved as a foundation for others, including and especially, communication. For some children with cerebral palsy acquiring the skills and knowledge necessary for interacting positively and successfully with peers is a challenge (Odom 2005, p.2). Disabled children tend to be less accepted by peers, may interact awkwardly and inappropriately in social situations and sometimes are socially incompetent. Disabled children may have difficulties in forming and maintaining relationships because the impairments caused by their disability limit or restrict them from participating in everyday activities with their peers (Odom 2005, p.2).

Some children with disabilities have difficulty in picking up social cues that allow them to cooperate with others (e.g. following the rules of a game, taking turns). This potentially can lead to poor social skills in communication with peers and later with schoolmates, while social interactions with peers are one of the key areas of social development. Significant determining factors of interpersonal communication are in the child's physical environment (Strain et al. 1986, p.29). The combination of these sorts of factors can lead children with a disability to be at risk of developing mental health difficulties, such as low self-esteem, and mental health disorders, such as depression. Many children thus would benefit from help with bridging their differences and finding ways to learn from and enjoy the company of others.

\section{Play as a tool for social competence development}

For young children, a primary component of social competence is establishing effective interactions with peers during play (Mathieson \& Banerjee 2010, pp.9-20; Craig-Unkefer \& Kaiser 2002, p.3; Zigler \& Bishop-Josef 2004, pp. 1- 13). Children, who are able to initiate play, enter ongoing play groups, appropriately respond to peers initiations, and resolve conflicts with peers will be socially competent in other aspects of peer relations (Howes \& Matheson 1992, pp.961-974).

Play is the primary context in which children build their emergent social communicative skills, as well as establish social competence (Mathieson \& Banerjee, 2010). Using social communication in play allows the child to satisfy their needs and desires, control the behaviour of others, participate in a social exchange, express opinions or feelings, engage in fantasy, obtain information, and provide information to others (Athanasiou, 2007; Craig-Unkefer \& Kaiser 2002; Zigler\& Bishop-Josef, 2004). Social play involves a high level of reciprocity and cooperation to work well and children learn about turn-taking, sharing, allowing others to go first, controlling emotions and putting the continuity of the play before their own immediate needs and wishes (Kay 2007, p.10). All of these social communicative behaviours coalesce to form the child's capacity for social competence.

Play is considered to be so important for children's development, that it is a universal right for all children under article 31 of the United Nations Convention on the Rights of the Child $(2013$, p.3). Whilst playing, children can experience, respond and adapt to a wide variety of social situations (Gleave and Cole-Hamilton 2012, pp.10-13). According to Ellis (1973), play fosters the behavioural variability of the child. Conventionally and currently, leaders in theories of early childhood education see play as fostering well-being, creative thinking skills, cognitive and social skills (Piaget 1962; Frost \& Sunderlin 1985).

To sum up, interactions with peers during play are the main component of the social competence of early years children, and include a number of social skills. The main of these skills were defined and are presented in figure 2 . 


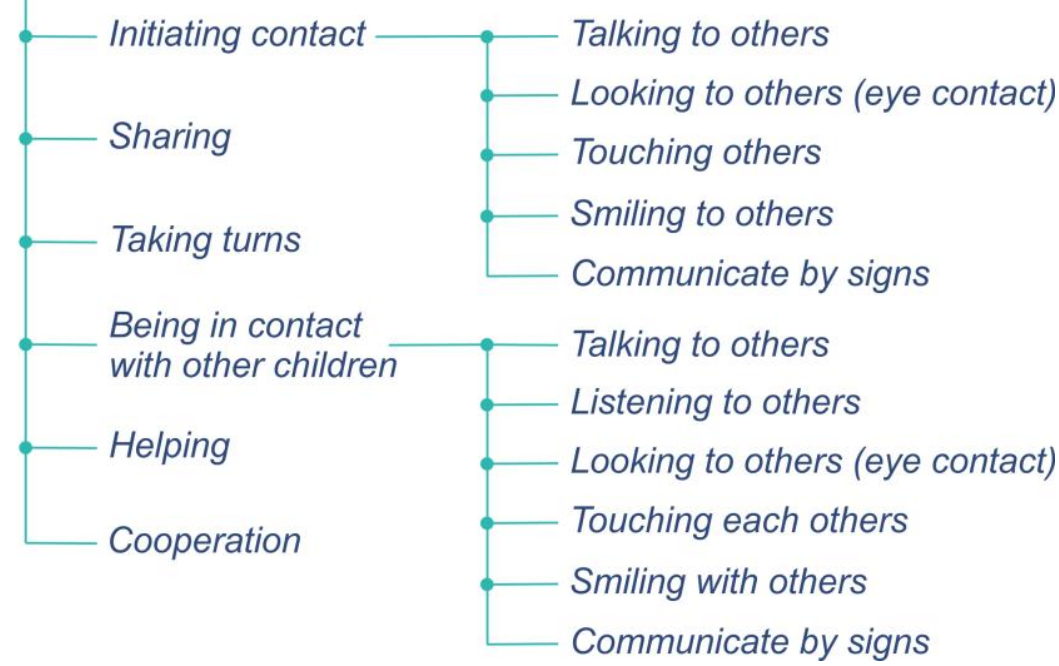

Figure 2 Social skills for early years children

Although most theories of play, such as the Psychoanalytic theories of Freud and Ericson, Cognitive theories of Vygotsky, Sutton-Smith, Bryner, etc. (Mellou 1994, pp.91-100) assume that play is imperative to children's development and learning, there is widespread debate regarding the magnitude of the benefits, and when these benefits occur during development. Despite considerations of the magnitude and occurrence of benefits of play, it is assumed generally to have advantages and provide areas for children's social growth. Through play between and among children, they learn how to get along with one another, to be helpful and share, to understand the consequences of their own behaviour, etc. (Pellegrini 2000, pp.360-366). Quality play builds confidence and reinforces a child's desire to explore and learn. Therefore, without knowing, during play, children participate fully in their own social development (Isenberg \& Jalongo 2006, pp.53-55).

\section{Peculiarities of play for children with cerebral palsy}

The play of children with disabilities often differs from that of their non-disabled peers. Play repertoires can be more limited, and play may occur less frequently in children with developmental disabilities (Li 1981, pp.121-126). Children with physical disabilities may find it hard to participate in games that other children play. Jennings et al. (1985, pp.162-169) presents characteristics of play of children with physical disabilities as more solitary, with a limited availability of materials.

Some children may find it difficult to approach their peers to engage in social activities. Not all children have the opportunity to meet and play with other children on a regular basis in nurseries and play groups. Specific aspects of play may be related to the type and severity of the disability (Kaplan-Sanoff et al. 1988, pp.137-161). Children with disabilities may experience physical, cognitive, emotional, or social difficulties or a combination of these. They may need more support with accessing the physical environment, to engage with toys and objects, encouragement to initiate and sustain interactions. For example, they may lack appropriate physical surroundings to play in and lack suitable playmates. These elements may conspire to foster an impression that children with disabilities experience basic play deficits. In fact, this impression may be completely false since the observed play differences could be environmental in origin (Hughes 2010, p.209), as children's development is directly linked to their ability to interact with their physical environment.

Children develop an understanding of themselves through their interactions with events and materials outside themselves. Beckung and Hagberg (2002) have investigated activity limitations and participation restrictions with gross and fine motor functions under the mobility, education and social relationship in children with cerebral palsy. They indicated that the effect of a child's impairment or activity limitation on participation might vary depending on environmental factors 
(Beckung and Hagberg 2002, pp.309-316). Environmental factors are defined as "the physical, social and attitudinal environment in which people live and conduct their lives" (WHO 2007, p.16). While the disability is present, environments have the ability to contribute or retard developmental process. The environment should offer children opportunities to actively explore surroundings, make decisions and follow through with their ideas, engage in different types of play, increase control over their bodies (Hohmann and Weikart, 1995). Objects for play and access to peers, for example, are essential components of major life situations of early years children.

\section{Play equipment as a mean for engagement into play}

The objects used in children's play are no less important than the game itself. Children have their own particular relationship with objects. Objects provide a means by which children can represent or express their feelings, concerns, or preoccupying interests. For children an unfamiliar object tends to set up a chain of exploration, familiarization, and eventual understanding, and often repeated sequence that will eventually lead to more mature conceptions of the properties (shape, texture, size) of the physical world (Garvey 1977, p.41). Objects represent a mediating element between a child and his/her world. They also may help children to explore what they can do and what are their limitations, thus contribute to develop self-image.

There is an enormous range of play equipment that a disabled child may require and use. It can be toys, heuristic baskets, activity boards, play sets, multisensory rooms, etc. (internet stores eSpecial Needs, Fat Brain Toys, Toys ' $R$ ' Us). For a child with cerebral palsy, toys can cater to specific areas of development or preference and can serve as a therapy aid (Hoffman et. al 2014).

However, finding play equipment that is appropriate for a child with cerebral palsy can be challenging. Bandri (2016) defines two ways in which toys can be chosen for disabled children. Firstly, the toys have to be such that they are geared to suit the abilities that the child currently has, or, secondly, they are such that they will move the child towards developing the abilities that he/she is working towards. Shusterman (2011) says that the key criteria for selecting toys should be ease of manipulation, minimal frustration, and something that attracts the child's attention. Children with more complex needs may experience difficulties with producing the same range of motion, muscle coordination, and dexterity that playing with play equipment designed for children with typical development may require. Consequently, children who do not have the physical or cognitive proficiency to play with the equipment provided may become bored or uninterested because of the lack of success. So what might seem like a 'normal', 'simple enough' for children without developmental difficulties, might pose obstacles for a child with cerebral palsy.

Nielsen (1992) with the 'Little Room' for children with visual and complex needs and Goldschmied and Jackson (1994) with the treasure baskets agree that it is important to give opportunities to explore space and objects without interference. The 'Little Room', as well as some other surroundings for children with complex needs is arranged in a way that the child can learn cause and effect. A certain movement leads to a certain tactile or auditory experience, e.g. handling a certain object can lead to production of different sound (Nielsen 1992). According to Gascoyne (2012, p.13), an inclusive way of encouraging play and development is sensory-rich play equipment. Early years children learn best and retain the most information when they engage their senses (Arnheim 1974 and Piaget \& Inhelder 2000).

Toys can be classified in different manners in dependence of the purpose of the classification. The diagram below (figure 3 ) presents examples that are currently available for children with cerebral palsy. They were contingently divided into groups which aid to development of particular areas. For each group from a range of equipment were taken the most representative. In the context of this study we are more interested in toys from the group "Social development", which will be discussed in more details later. 
It is important to notice that the same piece of play equipment often can be used for children with typical development as well as for children with cerebral palsy and based on investigation of the today's market there are no clear borders between them. Often, the only difference is the age range and level of physical and cognitive development to use certain equipment.

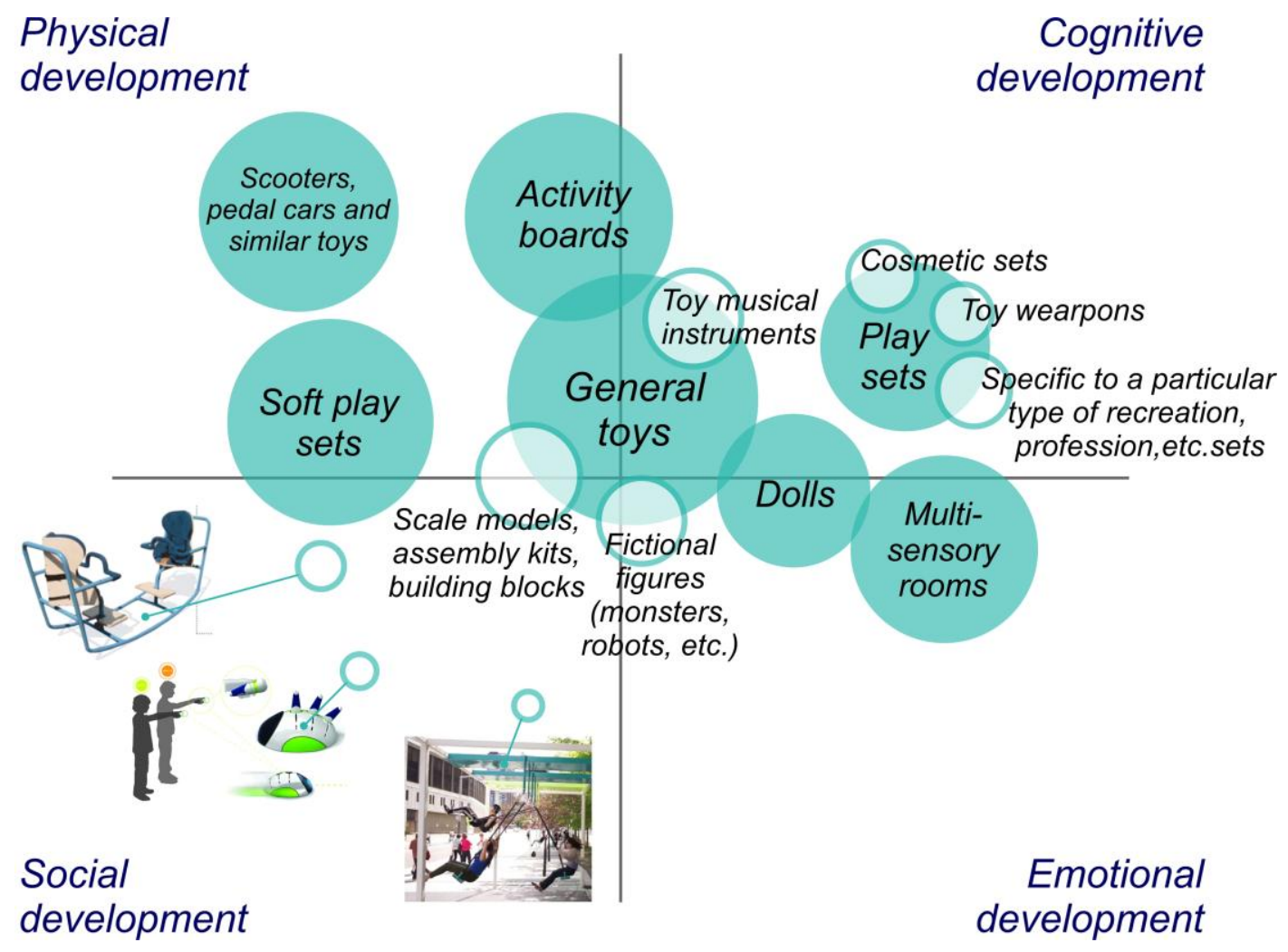

Figure 3 Examples of toys that are currently available for children with cerebral palsy

Let us consider three examples of existent equipment which perform social function and are intended for use by two or more individuals simultaneously.

One of the examples for promoting social communication of children is a Seesaw (figure 4), that was designed for children with cerebral palsy and supposed joint use for two children.

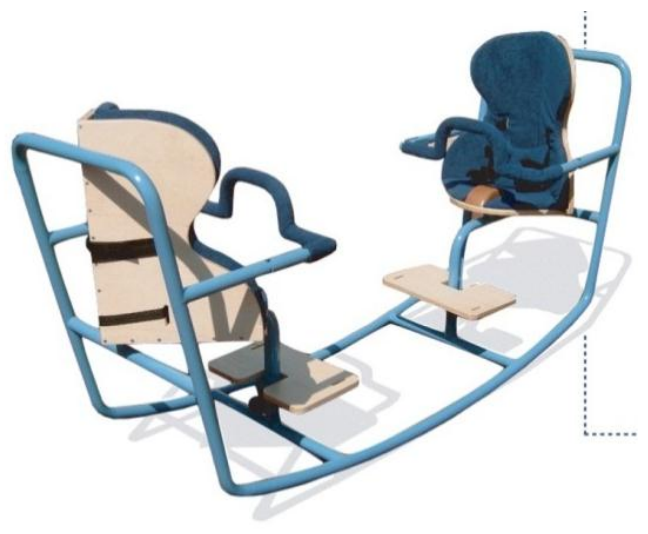

Figure 4 Seesaw for children with cerebral palsy. source: http://www.coroflot.com/kerenrelin/design-for-children (with a permission to use)

The positive side is that this Seesaw supposes cooperation and making eye contact with the other child -two of the skills of the repertoire of social competence. It has assisting facilities designed 
especially for children with cerebral palsy. However, there are also weaknesses, such as lack of attractiveness for a child, and the inability to use it without the help of an adult.

Another example is the Gobug interactive toy (Katz and Rim 2011) (figure 5). It helps facilitate a comprehensive social learning experience, not just for children but individuals of all ages. Two three children can play with this toy simultaneously together. Every user takes ownership of a single controller. While each user points out his/her remote in a particular direction, the Gobug moves around in the combined direction of active controllers. The more these controllers are in synchrony, the faster the Gobug moves in the same guided direction. Gobug will activate only when 2 or more controllers are in-hand. It helps users work together on verbal, physical and non-verbal communicative levels. However, Gobug was designed for school age children with autism spectrum disorder, and does not take into account physical needs and peculiarities of children with cerebral palsy.
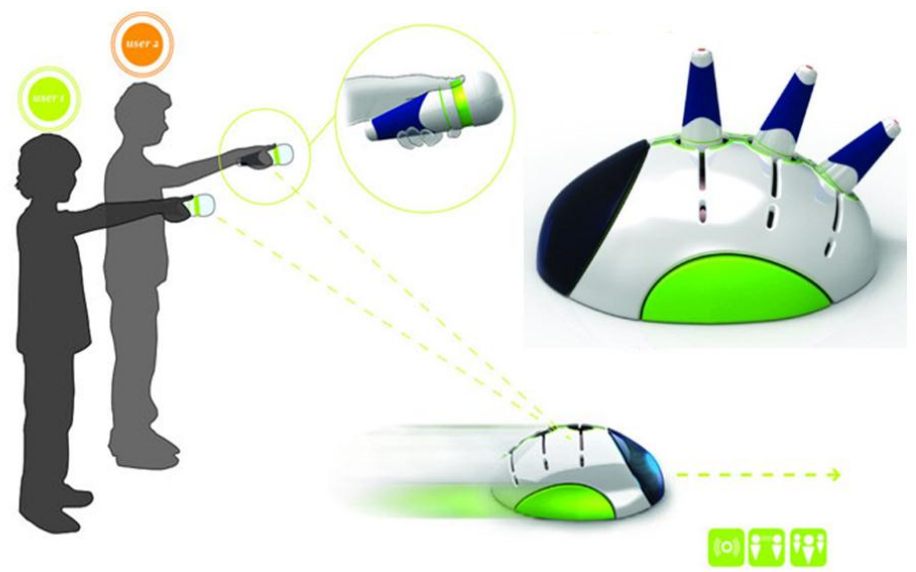

Figure 5 Gobug interactive toy. source: http://www.core77.com/posts/19262/autism-connects-gobug-interactive-toy19262 (with a permission to use)

An example of a play tool that supposes sharing and develops certain social skills is an Art installation - Montreal's "Musical Swings". The idea of the swings is that swinging sets off musical notes, and together forms a melody (figure 6). So, the aim is cooperation and obtaining a common result - a melody. This installation, however, does not require a joint use and can be utilized independently. It is designed not for early years children with cerebral palsy, as they may need more support with accessing these swings.

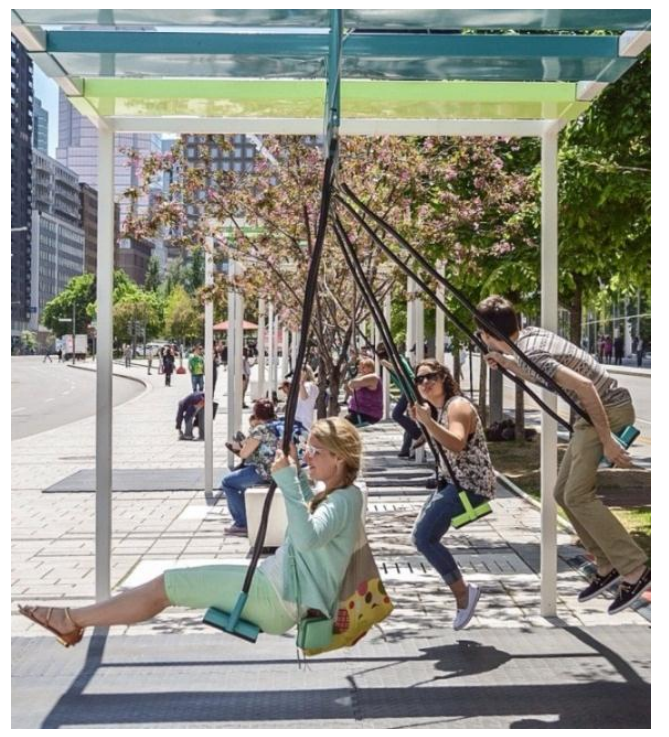

Figure 6 Montreal "Musical Swings". source: https://www.mtl.org/en/what-to-do/festivals-and-events/21-balancoiresmontreal (with a permission to use) 
There are very limited options in the market when it comes to toys specifically designed for children with cerebral palsy. The majority of the available examples have not been designed with considering the challenges of such children but are rather intended for any child. Available toys/toy sets take into account mainly physical abilities of children, but when designing for these children their social needs also should be a concern for toy designers, beside their abilities (Hassenzahl et al. 2012, p.5).

From the discussion above, some criteria of child friendly design which play equipment for children with cerebral palsy should have can be defined, such as: appropriateness for developmental level, focusing on strengths to minimize possible frustration, visual attractiveness, intuitiveness and positive feedback to carry rewards to children, sensory, and ergonomic to correspond to the child's anthropometry (figure 7).

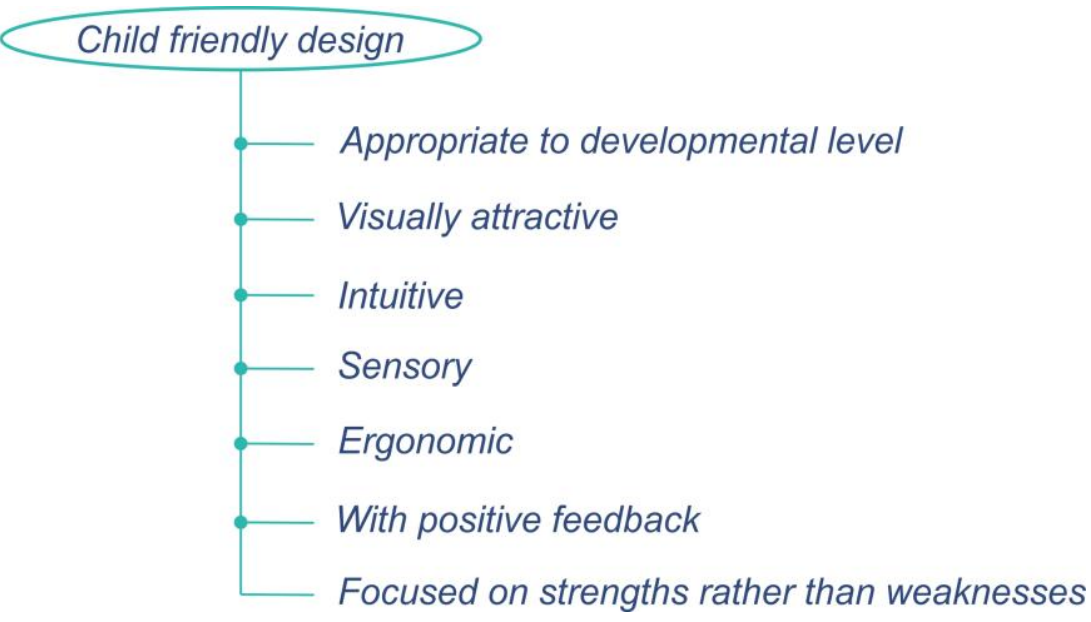

Figure 7 Criteria of play equipment for children with cerebral palsy

\section{Theoretical concept of play equipment for social competence development}

Play equipment in this study is treated as a tool for engaging children in social peer interactions by means of an object. When designing play equipment for social development, it is practically impossible to create a form, appearance, etc. that directly relates to functions of social development. But if we consider design as an interface for meaning-making, the designer's task shifts to constructing semiotic content that can trigger cognitive and emotional processes of children for the intended perception of the play equipment that can engage and thus develop specific social skills (figure 2 ).

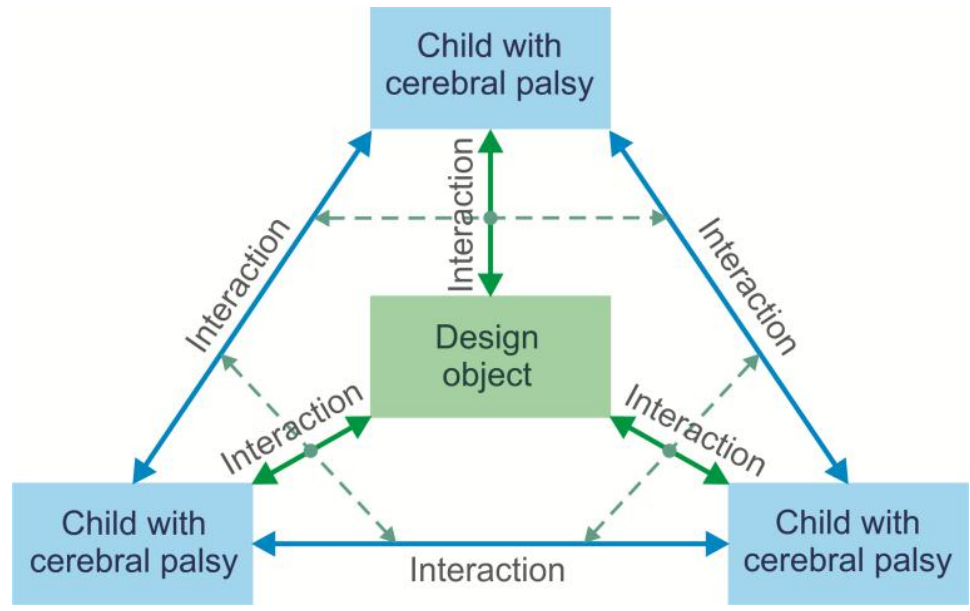


In the context of this research this means encouraging aspiration to interact with the designed objects and building social interactions through interacting with these objects (figure 8 ). The triangular model of relationship between person-object-person was discussed by Niedderer (2007, p.6). Such a design model links cognitive and emotional processes of communication with the designed object. Play equipment should enable and guide children in creating understanding and following behaviours that triggered by contact with the designed objects.

Children connect certain meanings with certain carefully chosen material objects in response to the immediate focus of their interest. This supports the concept that reality depends not only on the intentions, which are embedded in the design, but the interpretation of children who experience designed object. Moreover, the existing rules that govern play, but which are not inherent in the object, may influence the perception of the object. Perception is usually situated within various contexts of social processes and social relations where meaning is represented (Halliday 2005, pp.59-82). Representations are context-bound. This may suggest the necessity of understanding the context in which children interact with design objects and its influence on their meaning-making. Also the ways of meaning-making determine specific social situations and social relations where this meaning is presented.

Play equipment in this study is regarded as a part of the physical and social environment or as a tool for two or more children to play with. This project looks on play equipment not only as triggers of emotions and certain responses on them from children but focuses on encouraging social interactions between children mediated by those objects. The concept of objects around which social networks are form was put forward by Engeström (2005). He developed the theory of 'objectcentred sociality'. It describes the phenomenon whereby shared objects are the means by which people connect to each other to form social relationships and networks. According to this concept, links are created not just between people, but between people and objects, or around objects. Social objects in this case can be a central points of interpersonal interaction. Play equipment should trigger interactions between children not only around itself but by means of itself.

\section{Design guidelines}

To design for children play equipment that encourages their social development, design criteria should be developed. Based on the analysis of related literature and existing examples of design objects, it is possibly to identify characteristics which play equipment should have in the context of social development.

Design criteria represented in the form of the scheme (figure 9) and have two levels. The first one is indicators from the design position, and the second one - indicators of purpose.

The levels are interrelated and implementation of criteria from the second level depends on the realisation of the first level's criteria. At the top of the scheme is play equipment which should have a child-friendly design to be engaging - the first level of criteria. Child-friendly design means that equipment should be intuitive, sensory, visually attractive, developmentally appropriate, with positive feedback, focused on strengths, ergonomic, and safe. Through child-friendly design, play equipment can empower children to participate in open-ended group play, during which children are led by the equipment to practice social skills and to foster self-confidence. Social competence involves a range of skills and refers to the smooth sequential use of these skills in an effort to establish an ongoing social interaction. Social skills are a collection of isolated and discrete learned behaviours gender (Brownell 1990, p.840). The main social skills that early years children should develop competence in include: sharing, cooperation, taking turns, helping, initiating interactions, making contact with other children. These social skills, together with self-confidence, are criteria of the second level. 


\section{Design guidelines}

\section{Play equipment to encourage the development of the social competence}

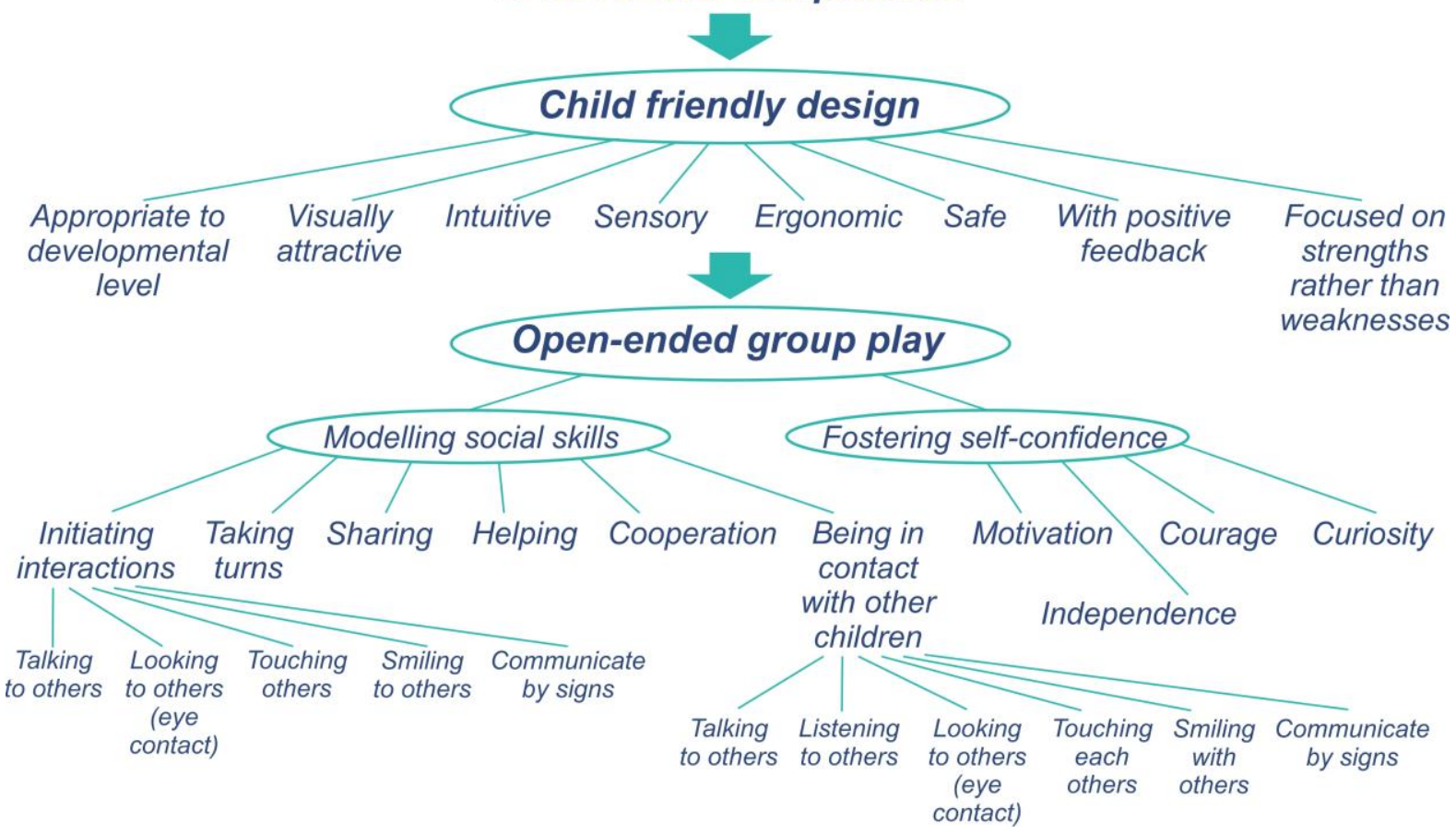

Figure 9 Design guidelines

Let us consider child-friendly design criteria in more details:

Play equipment should be intuitive. The concept of intuitive use of objects was studied by Blackler et al. (2007, pp.4-24). She formulated a definition: "Intuitive use of products involves utilising knowledge gained through other experience(s). Therefore, products that people use intuitively are those with features they have encountered before. Intuitive interaction is fast and generally nonconscious, so people may be unable to explain how they made decisions during intuitive interaction". Intuitive use will allow children to play with the equipment maximally independently with minimal help and guidelines from adults. Intuitiveness is especially significant while designing products for children with disabilities as it may allow them to feel more confident and convenient, allow accept the product and minimize rejection. The whole products and its individual parts should communicate and transfer a message, so that children as users know how the product should be utilized. In this case children can focus on what they want to do instead of how, with minimal help from adults.

Play equipment should be sensory. Children learn best and retain the most information when they engage their senses. Sensory element criterion shows if the play object has characteristics that appeal to any of the five senses (sight, touch, hearing, smell and taste) or give some sensory response in case of cause and effect toys. Sensory-rich play is an inclusive way of encouraging learning and development, with the hands-on approach appealing to children with different thinking and learning styles (Gascoyne 2012, p.13). For children with special needs, the detail of colour, texture, smell and lighting can have a much greater impact, depending on their disability. These things can be a source of discomfort and pleasure, as well as information, entertainment, education and reward (Bishop 2012). These characteristics are considered on the basis of lights, sounds, texture, smell, and taste. Visual characteristics and children's reactions to them were studied by Savva (2003, pp.300-313) and Savva \& Trimis (2009, pp.527-539). Object perception through the 
touch was discussed by Klatzky \& Lederman (2003). Bensafi et al. (2002), and Herz \& Engen (1996, pp.300-313) studied physiological effect of the smell.

Play equipment should be visually attractive. Visual perception is dominant among all the human perceptual activities because it supplies first-hand sensory experience ( Myers 1989). Play equipment with attractive visual image is more engaging. It can also contribute in keeping children's attention for longer.

Play equipment should be developmentally appropriate. Play equipment intended for younger than the target group children can be boring and uninterested, while equipment for older children can be too complicated. This may lead to inability to play with the play equipment provided and to loss of interest. Moreover, further it may lead to passivity in playing in general. This criterion is hard in implementation because of developmental difference of children even in one age group. The way to overcome this is designing open-ended equipment without stress on functional fixedness and taking into account physical, cognitive, emotional and social peculiarities of children.

Play equipment should have positive feedback to motivate children to continue current task, reach new results and try new activities. It can stimulate and prolong play, and raise self-confidence.

Play equipment should be focused on strengths rather than weaknesses. It is one of the main criteria in order to shift the perception of disability as a limitation to a more positive way. Children see and percept outer world in their own way and adapt to it depending on their abilities. It is necessary to find specific approaches and put the right priorities which correspond to children's needs and wishes.

Play equipment should be ergonomic and correspond to child's anthropometry (Goloborodko 2012, pp.21-25, 58-73). Anthropometric data helps to evaluate the fit between children, play equipment and physical environment. An understanding of this fit is critical to ensure that children can use play equipment intended for them. It protects them from harm by ensuring that hazards are properly guarded or placed out of reach.

Play equipment should be safe for reducing the potential for injuries. A list of essential safety requirements are set out in the Toys (Safety) Regulations 2011.

\section{Conclusion}

This paper has outlined the context and the key concepts regarding the development of social competencies of children with cerebral palsy through play and engagement in play through play equipment. To understand the peculiarities of the children and to define criteria and requirements for designing play equipment, the discussion began with the conception of cerebral palsy and an outline of the current status of medical and social views on cerebral palsy. This was followed by the discussion of the importance of the development of social competencies. Based on this, the paper discussed play and play equipment as tools for gaining necessary social skills. The contextual review defined the theoretical concepts and outlined the design criteria for creating a new model of play equipment.

Future research will develop a number of design ideas through ideation and brainstorming based on these criteria. Design guidelines and design ideas from this stage will be used for further refinement and development after collecting data from observations of children and interviews with their parents. One design idea will be chosen for implementation and intervention. Data gathered in observations before and after the design intervention will be compared in order to determine any changes in children's social interactions.

The paper highlight the difficulties of peer-to-peer interactions experienced by children with cerebral palsy and underline peculiarities of their playing with play equipment provided. The research will contribute new understandings of design for open-ended group play and will provide a set of design guidelines for this specialist play equipment. This new design model is intended to 
empower and lead children through the process of obtaining and practising peer social skills to be socially competent. It is also aimed at changing social perceptions of cerebral palsy and shifting the accent from limitation to potential and benefit of the children with cerebral palsy.

\section{References}

Arnheim, R. (1974) Art and visual perception: A psychology of the creative eye. University of California Press, Berkeley

Australian Early Development Census (AEDC) (2011) Guide to social competence. Resources for Queensland early childhood education and care services, p.2

Bandri, R. (2016) Toys for Children with Cerebral Palsy [online]. Buzzle TM. http://www.buzzle.com/articles/toys-for-children-with-cerebral-palsy.html

Beckung E, Hagberg G. (2002) Neuroimpairments, activity limitations, and participation restrictions in children with cerebral palsy. Developmental medicine and child neurology, 44 (5), pp.309-16.

Bensafi, M., Rouby, C., Farget, V., Bertrand, B., Vigouroux, M., Holley, A. (2002) Autonomic Nervous System Responses to Odours: the Role of Pleasantness and Arousal, Chemical Senses, 27(8), pp.703-709, https://doi.org/10.1093/chemse/27.8.703

Bishop, K. (2012) Designing learning environments for all children: Variety and richness [online]. Play for all. [Accessed 4 May 2017]. Available at: https://laurenkateblake.wordpress.com/2012/04/10/designinglearning-environments-for-all-children-variety-and-richness/

Blackler, A.L., Popovic, V., Mahar, D.P. (2007) Empirical investigations into intuitive interaction: a summary. MMI-Interaktiv 13, pp. 4-24.

Blandon, A.Y., Calkins, S.D., Grimm, K.J., Keane, S.P., O'Brien, M. (2010) Testing a developmental cascade model of emotional and social competence and early peer acceptance. Dev Psychopathol.,22(4), pp.737748. doi:10.1017/S0954579410000428.

Brownell, C. (1990) Peer social skills in toddlers: competences and constraints illustrated by same-age and mixed-age interaction, Child development, 61, pp.838-848.

Children's health (2017) Social competence [online]. Encyclopaedia of Children's health. [Accessed 4 November 2017]. Available at: http://www.healthofchildren.com/S/Social-Competence.html

Cogher, L., Savage, E. and Smith, M.F. (1992) Cerebral palsy: the child and the young person. London: Chapman \& Hall Medical.

Craig-Unkefer, L. A., \& Kaiser, A. P. (2002). Improving the Social Communication Skills of AtRisk Preschool Children in a Play Context. Topics In Early Childhood Special Education, 22(1), p.3.

Ellis, J.J. (1973) Why People Play. Englewood Cliffs, NJ: Prentice-Hall.

Engeström, J. (2005) Why some social network services work and others don't - Or: the case for objectcentered sociality [online]. Zengestrom. [Accessed 7 November 2016]. Available at:

http://www.zengestrom.com/blog/2005/04/why-some-social-network-services-work-and-others-dont-orthe-case-for-object-centered-sociality.html

EYFS (2014) Statutory framework for the early years foundation stage. Setting the standards for learning, development and care for children from birth to five. Department for Education (DfE), pp.7-13 https://www.gov.uk/government/publications/early-years-foundation-stage-framework--2

Fani, T., Ghaemi, F. (2011) Implications of Vygotsky's Zone of Proximal Development (ZPD) in Teacher Education: ZPTD and Self-scaffolding, Procedia - Social and Behavioral Sciences, 29, p.1550

Farrell, M. (2008) Educating special children" an introduction to provision for pupils with disabilities and disorders. Abingdon: Routledge.

Frost, J.L. \& Sunderlin, S. (1985) When Children Play. Association for Childhood Education International. Wheaton, MD.

Gagnon, S. G. and Nagle, R. J. (2004), Relationships between peer interactive play and social competence in atrisk preschool children. Psychol. Schs., 41, pp.173-189. doi:10.1002/pits.10120

Garvey, C. (1977) Play. Cambridge, Massachusetts: Harvard University Press, p.41.

Gascoyne, S. (2012) Treasure Baskets And Beyond: Realizing The Potential Of Sensory-Rich Play. [online]. McGraw-Hill Education (UK), p.13. [Accessed 24 July 2016]. Available at: http://www.mheducation.co.uk/openup/chapters/9780335246441.pdf

Gleave, J. and Cole-Hamilton, I. (2012) A world without play: A literature review [online]. Play England, pp.413. [Accessed 2 August 2016]. Available at: http://www.playengland.org.uk/media/371031/a-worldwithout-play-literature-review-2012.pdf

Goldschmied, E. and Jackson, S. (1994) People under Three: Young Children in Day Care. London: Routledge 
Goldstein, J. (2012) Play in children's development, health and wellbeing [online]. Brussels: Toy Industries of Europe, pp.5-8. [Accessed 2 August 2016]. Available at: http://www.ornes.nl/wpcontent/uploads/2010/08/Play-in-children-s-development-health-and-well-being-feb-2012.pdf

Goloborodko, V. (2012) Ергономіка для дизайнерів, ХДАДМ [Ergonomic for designers], pp.21-25, 58-73

Guralnick ,M.J., Connor, R.T., Hammond, M.A., Gottman, J.M., Kinnish, K. (1996) Immediate effects of mainstreamed settings on the social interactions and social integration of preschool children. American Journal on Mental Retardation, 100(4), pp.359-377.

Guralnick, M.J. (2001) A framework for change in early childhood inclusion. In M.J. Guralnick (Ed.) Early childhood inclusion: Focus on change. Baltimore: Brookes, pp.3-35.

Halliday, M.A.K. (2005) On matter and meaning: the two realms of human experience. Linguistics and the Human Sciences, vol.1(1), pp.59-82.

Hari, M., Akos, K. (1988) Conductive Education. London: Routledge, p. 159

Hassenzahl, M., Heidecker, S., Eckoldt, K., Diefenbach, S., \& Hillmann, U. (2012). All you need is love: Current strategies of mediating intimate relationships through technology. ACM Trans. Comput.-Hum. Interact., 19(4), pp.1-19. https://pdfs.semanticscholar.org/d66c/8b50134400c6eac0146927c23e1ade8efb71.pdf

Herz, R.S. \& Engen, T. (1996) Odor memory: Review and analysis. Psychonomic Bulletin \& Review 3(3), pp.300313. https://doi.org/10.3758/BF03210754

Hinchcliffe, A. (2007) Children with cerebral palsy: a manual for therapists, parents and community workers. 2nd ed. London: Sage Publications.

Hoffman, A., Wang, K., Yeh, K., Schectman, T., Ferrise J. (2014) A comprehensive guide to finding the right toy for your child with special needs [online]. A Friendship Circle EBook. [Accessed 17 March 2016] Available at: http://www.friendshipcircle.org/blog/ebooks/special-needs-toy-guide/

Hohmann, M. and Weikart, D. (1995). Educating Young Children: Active Learning Practices for Preschool and Child Care Programs [online]. USA: The High/Scope Press, pp.16-18 [Accessed 12 March 2016]. Available at: http://trinitypreschoolsc.org/wpcontent/uploads/Active_Learning_The_Way_Children_Construct_Knowledge-1.pdf

Isenberg|, J.P. Jalongo, M. R. (2006) Creative Thinking and Arts-Based Learning: Preschool Through Fourth Grade. Pearson, pp.53-55 https://www.education.com/reference/article/importance-play--socialemotional/

Jennings, K.D., Connors, R.E., Stegman, C.E., Sankaranarayan, P., Mendelsohn, S. (1985) Mastery motivation in young preschoolers: Effect of a physical handicap and implications for educational programming. Journal of the Division for Early Childhood, 19(2), pp.162-169.

Katz, G., Rim, T. (2011) Autism Connects: Gobug Interactive Toy. CORE77, May 09. The design competition Autism Connects winner. http://www.core77.com/posts/19262/autism-connects-gobug-interactive-toy19262

Katz, I. G., \& McClellan, D. E. (1997). Fostering children's social competence: the teacher's role. Washington, DC: National Association for the Education of Young Children. In H.S. Han \&K.M. Kemple (2006) Components of Social Competence and Strategies of Support: Considering What to Teach and How. Early Childhood Education Journal, Vol. 34(3), pp.241-243.

Kaplan-Snoff, M., Brewster, A., Stillwell, J., \& Bergen, D. (1988). In D. Bergen (Ed.) Play: As a medium for learning and development: A handbook of theory and practice. Portsmouth, NH: Heinemann, pp. 137-161.

Kay, J. (2007) Behavioural, emotional and social difficulties. Continuum Int.Publ.Group, p.2, 10.

Klatzky, R.L. and Lederman, S.J. (2003) Touch, in ed. by A.F. Healy, R. Proctor, I.B. Weine, Handbook of Psychology: Experimental Psychology 4., Wiley, New York.

Kozulin, A. (1990) Vygotsky's psychoiogy: A biography of ideas. Cambridge, MA: Harvard University Press, p.254.

Ladd, G. W. (2000). The fourth R: Relationships as risks and resources following children's transition to school. American educational research association division e newsletter, 19(1), pp.7-11.

Landsman, G.H. (2005) Mothers and models of disability. The Journal of medical humanities, 26 (2-3), pp.121139

Landsman, G.H. (2006) What evidence, whose evidence?: Physical therapy in New York State's clinical practice guideline and in the lives of mothers of disabled children. Soc. Sci. Med., 62, pp.2670-2680

Li, A.K. (1981) Play and the mentally retarded child. Mental Retardation, 19, pp.121-126.

Mathieson, K., \&Banerjee, R. (2010). Preschool peer play: The beginnings of social competence. Educational \& Child Psychology, 27(1), pp.9-20.

McConnell, S. R., \& Odom, S. L. (1999). A multimeasure performance-based assessment of social competence in young children with disabilities. Topics in Early Childhood Special Education, 19(2), 67-74. 
Meadows, S. (1993) The child as thinker: The development and acquisition of cognition in childhood. London: Routledge, pp.104-126.

Mellou, E. (1994) Olay Theories: A contemporary review, Early Child Development and Care, vol. 102(1), pp.91100

Myers, J.F. (1989) The language of visual art: perception as a basis for design. Holt, Rinehart and Winston

My Child (2016) Inspiration [online]. [Accessed 5 March 2017]. Available at: http://www.cerebralpalsy.org/inspiration

NCCA (National Council for Curriculum and Assessment) (2004) Towards a Framework for Early Learning [online], p.12. [Accessed 2 April 2016]. Available at:

http://www.ncca.ie/en/Publications/Consultative_Documents/Towards_a_Framework_for_Early_Learning Executive_Summary.pdf

NHS (The National Health Service of the UK ) (2016) Cerebral Palsy [online]. [Accessed 27 January 2016]. Available at: http://www.nhs.uk/conditions/Cerebral-palsy/Pages/Introduction.aspx

Nielsen, L. (1992) Space and Self: Active Learning by Means of the Little Room. Sikon

Niedderer, K. (2007). Designing Mindful Interaction: The Category of the Performative Object. Design Issues, 23 (1), pp. 3-17 http://www.mitpressjournals.org/doi/pdf/10.1162/desi.2007.23.1.3

Odom S.L. (2005) Peer-related Social Competence for Young Children with Disabilities [online]. Indiana University, USA, p.2. [Accessed 2 August 2016]. Available at: http://www.childencyclopedia.com/sites/default/files/textes-experts/en/829/peer-related-social-competence-for-youngchildren-with-disabilities.pdf

Palmonari, A., Doise, W. (1984) Social interaction in individual development. Cambridge University Press.

Parkes, J., White-Koning, M., Dickinson, H., Thyen, U., Arnaud, C., Beckung, E., Colver, A. (2008) Psychological problems in children with cerebral palsy: A cross-sectional European study. Journal Of Child Psychology And Psychiatry 49, pp.405-413.

Parker, J.G., Asher, S.R. (1987) Peer relations and later personal adjustment: Are low-accepted children at risk? Psychological Bulletin, 102(3), pp.357-389.

Pellegrini, A. D., \& Bartini, M. (2000). An empirical comparison of methods of sampling aggression and victimization in school settings. Journal of Educational Psychology, 92, pp.360-366.

Piaget J., Inhelder B. (2000) The development of perception. Basic Books, New York

Piaget, J. (1962) Play, Dream and Imitation translated by C. Gattegno and F.M. Hodgson. London: Routledge and Kegan Paul, p.149.

Rogoff, B. (1990) Apprenticeship in thinking: Cognitive development in social context. New York: Oxford University Press, pp.171-188

Rogoff, B. (1998) Cognition as a collaborative process, In W. Damon (Ed.), Handbook of Child Psychology (5th ed.). New York: John Wylie, p.686

Rolfe, S. \& Linke, P. (2011). Everyday learning about responding to the emotional needs of children. Deakin: Early Childhood Australia.

Rozsahegyi, T. (2014) A bio-ecological case-study investigation into outlooks on the development and learning of young children with cerebral palsy. University of Warwick, Centre for Education Studies, pp.21,47-53

Savva, A., (2003) 'Young Pupils` Responses to Adult Works of Art'. Contemporary Issues in Early Childhood, vol. 4, pp.300-313.

Savva, A., Trimis, E., (2009) 'Artistic learning in relation to young children's chorotopos: An in depth approach to earlychildhood visual culture education'. Early Childhood Education, vol 36, pp.527-539.

Shusterman, L. (2011) Bikes, Toys/Gifts \& Gadgets [online]. CP Daily Living Journal http://cpdailyliving.com/developmental-toys/

Strain, P.S., Guralnick, M.J., Walker, H.M. (1986) Children's social behaviour. Development, assessment, and modification. Academic Press Inc. London, p.29

Sutton, A. (2010) General editor's foreword. In J. Graham, C. McGuigan and G. Maguire (eds) Intelligent love. Birmingham: Conductive Education Press.

Toys (Safety) Regulations 2011 [online]. [Accessed 15 August 2017]. Available at: http://www.legislation.gov.uk/uksi/2011/1881/contents/made

Vygotsky, L. (1978) Mind in society. Cambridge, MA: Harvard University Press, p. 57, 79-91.

Vygotsky, .L (1929) The collected works of L.S. Vygotsky. Vol.2: The fundamentals of defectology (abnormal psychology and learning disabilities) (R.W.Rieber \& A.S. Carton, Eds.). NY: Plenum Press. [online]. [Accessed 6 February 2016]. Available at: https://www.marxists.org/archive/vygotsky/works/1929/defectology/ 
Whitebread, D. (2012) The importance of play. [online]. Brussels: Toy Industries of Europe, pp.5-6 [Accessed 25 July 2016]. Available at: http://www.importanceofplay.eu/IMG/pdf/dr_david_whitebread_-

_the_importance_of_play.pdf

World Health Organization's (WHO) (2007) The World health report. Mental health: new understanding, new hope. WHO, p.16-17.

Zigler, E., \& Bishop-Josef, S. (2004). Play under siege: A historical overview. In E. F. Zigler, D.G. Singer, \& S. J. Bishop-Josef (Eds.), Children's play: The roots of reading, pp.1-13. Washington, DC: Zero to Three/National Centre for Infants, Toddlers and Families.

About the Authors:

Ganna Borzenkova is a PhD candidate at the University of Wolverhampton, UK. Her research presents an investigation into designing play equipment for encouraging peer-to-peer social interactions of children with cerebral palsy as part of developing their social competence.

Dr Kristina Niedderer is a Professor of Design and Craft at the University of Wolverhampton, UK. She is recognised internationally for her work on mindfulness in design and in research methodology, as well as for building the field of craft research.

Dr Tunde Rozsahegyi is a Senior Lecturer in Special Educational Needs, Disability and Inclusion Studies at the University of Wolverhampton, UK. Her research interests are: inclusive pedagogies; conductive education and international consultancy and training. 